\title{
Taxonomic peculiarities of marcescent oaks (Quercus, Fagaceae) in southern Portugal
}

\author{
Carlos Vila-Viçosa (*), Francisco M. Vázquez (**), Catarina Meireles (***) \\ \& Carlos Pinto-Gomes (*)
}

\begin{abstract}
Vila-Viçosa, C., Vázquez, F.M., Meireles, C. \& Pinto-Gomes, C. Taxonomic peculiarities on marcescent Oaks (Quercus, Fagaceae) in southern Portugal. Lazaroa 35: 139-153 (2014).

Geobotanical studies on marcescent groves in southern Portugal have led to a clarification and updating of the taxonomical status of some Quercus species, after ambiguous and specific collections recorded through extensive fieldwork. We highlight the situation of $Q$. canariensis Willd. in Portugal, mainly referring to the hybrid-species $Q$. x marianica $\mathrm{C}$. Vicioso, whose new status is proposed here. We also confirm and discuss the occurrence of two dubious taxa (Q.alpestris Boiss. and Q. estremadurensis O. Schwarz) for Portuguese flora that are not listed or recognized in the main works, and we note some nomenclatural issues for the first ( $Q$. alpestris). Likewise, reference is made to another two nothospecies resulting from hybridization that have recently been recognized in this context, in addition to another four hybrids that are already known but still unfamiliar to the scientific community due to the controversial issue of hybridization within this genus. This study reveals the importance of taxonomical surveys for community ecology.
\end{abstract}

Keywords: Quercus, Taxonomy, Marcescent groves, Southern Portugal, White-Oak.

Resumen: Vila-Viçosa, C., Vázquez, F.M., Meireles, C. \& Pinto-Gomes, C. Peculiaridades taxonómicas sobre robles marcescentes (Quercus, Fagaceae) en el sur de Portugal. Lazaroa 35: 139-153 (2014).

Los estudios geobotánicos realizados sobre robledales marcescentes en el sur de Portugal han dado lugar a la actualización del estatus taxonómico de algunas especies de Quercus, tras un extenso trabajo de campo y consulta de material de herbario. Se destaca la situación de Q. canariensis Willd. en Portugal, sobre todo a la especie hibridógena Q. x marianica C. Vicioso, cuya situación nueva se propone aquí. Además, se confirma y se discuten dos taxones dudosos (Q.alpestris Boiss. y Q.estremadurensis $\mathrm{O}$. Schwarz) para la flora portuguesa no reconocidos en las principales obras, y se adjuntan algunas notas nomenclaturales para el primero (Q. alpestris). Del mismo modo, se hace referencia a otras dos nothoespecies resultantes de la hibridación que recientemente han sido reconocidos en este contexto, además de otros cuatro híbridos que ya son conocidos, pero aún desconocidos para la comunidad científica debido a la controvertida cuestión de la hibridación dentro de este género. Este trabajo enfatiza la importancia de los estudios taxonómicos para el mejor conocimiento de los bosques.

Palabras clave: Quercus, Taxonomía, Robledales marcescentes, Sur de Portugal.

\section{INTRODUCTION}

As an extremely common phenomenon in Quercus genus, hybridisation entails heavy controversy and a highlighted debate topic, in the evolutionary context (BURGER, 1975; GRANT,
1981). As so, several works have been carried out on this subject, specifically in oaks (BENSON, 1962; HARDN 1975; Muller, 1951; PALMER, 1948; STEBBINS, 1950).

Due to the diversity of species and the ease with which they hybridise, in addition to the de-

* CIBIO. Centro de Investigação em Biodiversidade e Recursos Genéticos. InBIO Laboratório Associado. Universidade do Porto. Campus Agrário de Vairão. Rua Padre Armando Quintas. P 4485-661 Vairão, Portugal. Email: cvv@cibio.up.pt

**Departamento de Producción Forestal y Pastos. Centro de Investigación Agraria Finca La Orden-Valdesequera. Paseo de Roma, s/n,06800 Mérida. Email: frvazquez@hotmail.com.

*** Departamento de Paisagem, Ambiente e Ordenamento Universidade de Évora (Portugal). Rua Romão Ramalho, 59, P7000-671. Évora, Portugal \& Instituto de Ciências Agrárias e Ambientais Mediterrânicas (ICAAM). Universidade de Évora, Núcleo da Mitra, Ap. 94, 7002-554 Évora, Portugal. Email: cmeireles@uevora.pt. 
crease of primary forests that results from increase in agriculture and forestry to more intense work in the Mediterranean region (VICIOSO, 1950; SAÉNZ DE RIVAS \& RivAS-MARTíNEZ, 1971; Rivas-MartínEZ \& SAÉNZ, 1991; Llamas \& al., 1995; VÁZQUEZ, 1995; PENAS \& al., 1997; AlONSO \& al., 1999; VÁZQUEZ \& al., 2000; VÁZQUEZ \& al., 2003). All these studies evidence that the intra-generic diversity is intimately related with extended introgression in close species from genus Quercus (RUSHTON, 1993; BACILIERI \& al., 1996; RIESEBERG, 1997). This variety is normally a result of biogeographic patterns, modelled by climatology, edaphology and anthropogenic action (AXELROD, 1983; MANOS \& al., 1999, 2001), mainly by the increase in agriculture and forestry, which are the environmental gradients responsible for the hybridization process and the creation of hybrid zones, where populations of two or more related taxa contact to each other and change genetic information (ARNOLD, 1997; VÁZQUEZ \& al., 2001). Inclusively some authors (DoDD \& AFZAL-RAFII, 2004) reinforces that this gradients are even more important, comparing with the pollen origin, in the determination of hybrid-forest mass origin. Also others (COTTAM \& al., 1959; MULLER, 1952; VÁZQUEZ, 1995) stated that climatic conditions along phenological variations between species, reiterates that habitat modification is an important factor, in the establishment of new hybrids, unknown until recently.

Some recent works about marcescent groves and other types of vegetation (VILA-VIÇOSA \& al., 2012; AguiAr \& al., 2013) in Southern Portugal, highlight the necessity to clarify taxonomic cases, such as stabilized hybrids, new taxa and sintaxonomic groups with floristic particularities, where these forest types emerge as characteristic mature stages of typically Sub-Mediterranean ecotones, marking the transition between Temperate bioclimate and those genuinely Mediterranean (RIVAS-MARTíNEZ, 2007; GAVILÁN \& al., 2011; SCIANDRELLO \& al., 2013; VILCHES \& al., 2013).

In the Iberian Peninsula, there are 12 species and 3 subspecies of marcescent oaks. These are Quercus broteroi (Cout.) Rivas-Mart. \& C. Sáenz, Q. canariensis Willd.; Q. faginea subsp. faginea Lam.; Q.faginea subsp.alpestris (Boiss.) Maire; Q. lusitanica Lam.; Q. pauciradiata Penas, Llamas, Pérez-Morales \& Acedo; Q. orocantabrica
Rivas-Mart., Penas, Díaz \& Llamas; Q. petraea subsp. petraea (Mattuschka) Lieb.; Q. petraea subsp. huguetiana Franco \& G. López; Q. pubescens Willd.; Q. pyrenaica Willd.; Q. robur subsp. broteroana O. Schwartz and Q. robur subsp. estremadurensis (O. Schwarz) A. Camus. Some oaks has been suggested from a hybrid origin, for example $Q$. marianica $\mathrm{C}$. Vicioso, which is a subject of this article and $Q$. subpyrenaica Villar, referred by ABADiA \& al. (1996); HimRANe \& al. (2004) and SÁNCHEZ-De Dios \& al. (2006).

The aim of this paper is to investigate the treatment of taxa that display features, which resembles hybridization and consequent alteration of taxonomic and chorologic references within the Portuguese Flora.

\section{MATERIALS AND METHODS}

Field work was carried out between 2006 and 2012 , following sintaxonomic studies that referred to marcescent groves in central and southern Portugal. The study area was selected based on the diversity of particular edaphoclimatic typologies in the transition zone between deciduous and evergreen ecotones, with major necessity of sintaxonomic clarification and update.

For the taxonomic identification we used the main references CASTROVIEJO \& al (1986-2012), COUTINHO (1939), Franco (1971-1984) and Franco \& Rocha AFONSO (1994-2003), complemented by specific works on Quercus genus as Camus (1938), Vasconcellos \& Franco(1954), SAENZ DE Rivas \& Rivas-Martínez (1971), VÁZQUEZ \& al. (2003) and NAVARRO (2007). Taxonomic determinations of Quercus taxa were complemented by use of a scanning electronic microscope (Carl Zeiss EQ-01784) and binocular magnifier Olympus S2X7, coupled with a digital camera UCMAD3. As for the nomenclature referring to Quercus, as well as synonymies, this was assisted by online portals as Oak Name Checklist from International Oak Society, available at http://www.oaknames.org/search/index.asp, The Plant List, available at: http://www.theplantlist.org/tpl/search?q=Quercus and The International Plant Names Index, available at: http://www.ipni.org/ [Accessed December, 2012]. 
The materials studied were deposited in the HSS herbarium, and the type material was duplicated and also lodged in the MAF herbarium (HOLMGREN \& al., 1990, 2003). All materials studied are cited in Appendix I. All material listed in Appendix I not determined prior to this work was carefully studied, to identify new taxa or nothotaxa. Biogeographic information followed RIVASMARTíneZ (2007).

\section{RESULTS AND DISCUSSION}

We propose two taxa previously unrecognized in the Portuguese Flora, providing taxonomic clarification for the identification of $Q$. alpestris. The prevailing problem of distinguishing between $Q$. x marianica C. Vicioso and Q. canariensis Willd. in Portugal is also addressed. Two hybrids were detected during this study and these are described below, as well as new locations for taxa and hybrids already known.

Quercus alpestris Boiss. Elech. Pl. Nov.: 83 (1838) (lectotype: G-BOISS n.v.; isotype 1: g00358088!, isotype 2: g00358091!; isotype 3: P06857844!

Synonyms: $=Q$. lusitanica var, cuneifolia Lange, in herb. COI-WILLK 38881! Sierra Morena ad pagum Trasierra, 25/3 (1852); = Q. lusitanica subsp. alpestris (Boiss.) Nyman, Consp. Fl. Eur.: $661(1881)=Q$. lusitanica var. alpestris (Boiss.) Cout., Bol. Soc. Brot. 6: 68 (1888); = Q. lusitanica var. broter[o]i f. macrophylla Cout., Bol. Soc. Brot. 6: 69 (1888) (lectotype: COI n.v., Isotype 1: P06853571!; Isotype 2: P06857848!); $=Q$. lusitanica var. alpestris f. salicifolia Cout., Bol. Soc. Brot. 6: 68 (1888) (lectotype: COI n.v.); $=Q$. alpestris var. vulgaris (Cout.) A.Camus, Chênes, Texte 2: 166 (1939), nom. inval.; $\equiv Q . l u$ sitanica subsp. valentina var. salicifolia C.Vicioso, Bol. Inst. For. Invest. \& Exper. Madrid 51:108 (1950) (holotype: in MAIA n.v.; Paratype: MAIA6611!); $\equiv Q$. lusitanica subsp. valentina $\mathrm{f}$. obtusidens C.Vicioso, Bol. Inst. For. Invest. \& Exper. Madrid 51:108 (1950) (Holotype: in MAIA n.v.; paratype: MAIA6612!); इ Q. faginea subsp. alpestris (Boiss.) Maire, Fl. Afrique Nord 7: 100
(1961); = Q. faginea subsp. faginea var. alpestris (Boiss.) F.M.Vázquez, M.Gut. \& S.Ramos, Int . Oak 21: 128 (2010).

Description: Marcescent tree to $15 \mathrm{~m}$ tall; leaf ovoid-lanceolate, to oblong/lanceolate $0,8-5(5,8)$ $\mathrm{x} 0,6-1,4(1,8) \mathrm{cm}$, with narrow lamina, short and denticulate to serrate, mucronate. Glaucous abaxial surface, with a white-greyish pubescence, resultant from high density of stellate, fasciculate and multi-stellate trichomes, adpressed, with short and long rays, the long rays 12-17(19) $\mu \mathrm{m}$ long, the short ones with $(<20 \mu \mathrm{m}$ long), with more than 8 filaments (8-15). Secondary veins sinuate and more irregular than $Q$. broteroi. Petiole medium $(0.4-1,1 \mathrm{~cm})$. Male catkins with $2-4 \mathrm{~cm}$, with acute perianth lobes.

The presence of Q.alpestris Boiss in the Southern Iberian Peninsula is controversial, since the original type material collected by Boissier in 1837 is polymorphic, as typical of this taxon. The polymorphism is the cause of different interpretations such as Coutinho (1888), who considered $Q$. alpestris Boiss., synonymous with $Q$. hispanica $\alpha$. "Chêne de Gibraltar", Lam. Encycl. Meth. (Lamarck) 1: 723 (1785) (lectotype: P-LAM0382503! (upper specimen); isotype 1: P-LAM0380504! (single specimen); isotype 2: P-LAM0380502! (central specimen), but it is different for denticulate leaves, not mucronate, tomentose below, long petiole $(>0,8 \mathrm{~cm})$ and abundant stellate and fused-stellate trichomes, versus $Q$. alpestris Boiss, with denticulate to serrate leaves, mucronate teeth, below glabrescent to pubescent, petiole up to $0.9 \mathrm{~cm}$, with sinuate secondary ribs and abundant fasciculate, multiradiate and stellate trichomes; later named by CoutinHo (1888) as: $Q$. lusitanica var. broter[o]i f. macrophylla Cout., Bol. Soc. Brot. 6: 69 (1888) (lectotype: COI n.v., isotype 1: P06853571!; isotype 2: P06857848! and Lange (1852), such as: Q. lusitanica var, $c u$ neifolia Lange, in herb. COI-WILLK 38881 ! Sierra Morena ad pagum Trasierra, 25/3 (1852), or Vicioso (1950) described Q. lusitanica subsp. valentina var. salicifolia C. Vicioso, Bol. Inst. For. Invest. \& Exper. Madrid 51:108 (1950) and Q. lusitanica subsp. valentina f. obtusidens C. Vicioso. Bol. Inst. For. Invest. \& Exper. Madrid 51:108 (1950), all synonymous of Q. alpestris Boiss. 
Boissier (1837) also described as a new species in the herbarium $Q$. aegilopifolia Boiss. in GBOISS; in montibus circa Rondam, Alt. circ. 3000'. Mai (1837), then Boissier (1842) considered to be synonymous (" $Q$. alpestris Boiss., hoc referenda Q. aegilopifolia Boiss. Sched. Boissier 1842" (manuscr. Boissier) P06857878!, but actually synonym with $Q$. hispanica $\alpha$. "Chêne de Gibraltar", Lam. Encycl. Meth. (Lamarck) 1: 723 (1785), invalidated later by Endlicher (1848) $Q$. aegilopifolia Boiss. ex Endl., Gen. Pl. [Endlicher] Suppl. IV. II. 25. (1848) inv. nom. (lectotype: GBOISS n.v.; isotype 1: P06857823!; isotype 2: P06857842!; non Persoon 1807 (Q. aegilopifolia Pers., Syn. Pl. 2: 570 (1807) nom nud. the voucher sheet in P-LAM contained up to three different taxa with the "aegilop" leaf morphology from Spain (voucher one: P-LAM 0382505! (specimen 1), P-LAM 0382506! (specimen 2) and PLAM 0382507! (specimen 3)), also distinct taxa described by Boissier (1837) such as Q. aegilopifolia Boiss. ex Endl.

Due the high number of heterotypes, synonyms and even hybrids concerning the name " $Q$. hispanica", that may lead to misjudges and wrong morphological and nomenclatural analysis, the proposed solution is to consider a new name for the taxon of Lamarck (1785), previously named $Q$. hispanica $\alpha$. "Chêne de Gibraltar", Lam. Encycl. Meth. (Lamarck) 1: 723 (1785): Quercus gaditana F.M. Vázquez, C. Pinto-Gomes \& C. Vila-Viçosa nom. nov. (Figure 1; holotype: P-LAM0382503! (single specimen); isotype 1: P-LAM0382504! (single specimen); isotype 2: P-LAM0382502! (central specimen)

Diagnosis: Foliis ellipticis vel lanceolateoblongis, cuneato-attenuatis, dentato-serrata, dentibus acutis, adulta subtus glauco-tomentella, petiole longus $(>0,8 \mathrm{~cm})$, cupulae turbinatae, squamis ovato-suborbicularibus, acuminates, dorso valde gibbis; glande parva, ovate vel elliptica, apiculo glaberrimo vel tomentose. (Synonymous: $=Q$. hispanica Lam. $\alpha$. "Chêne de Gibraltar", Lam. Encycl. Meth. (Lamarck) 1: 723 (1785) inv. nom. $=Q$. aegilopifolia Boiss. ex Endl., Gen. Pl. [Endlicher] Suppl. IV. II. 25. (1848) inv. nom.).

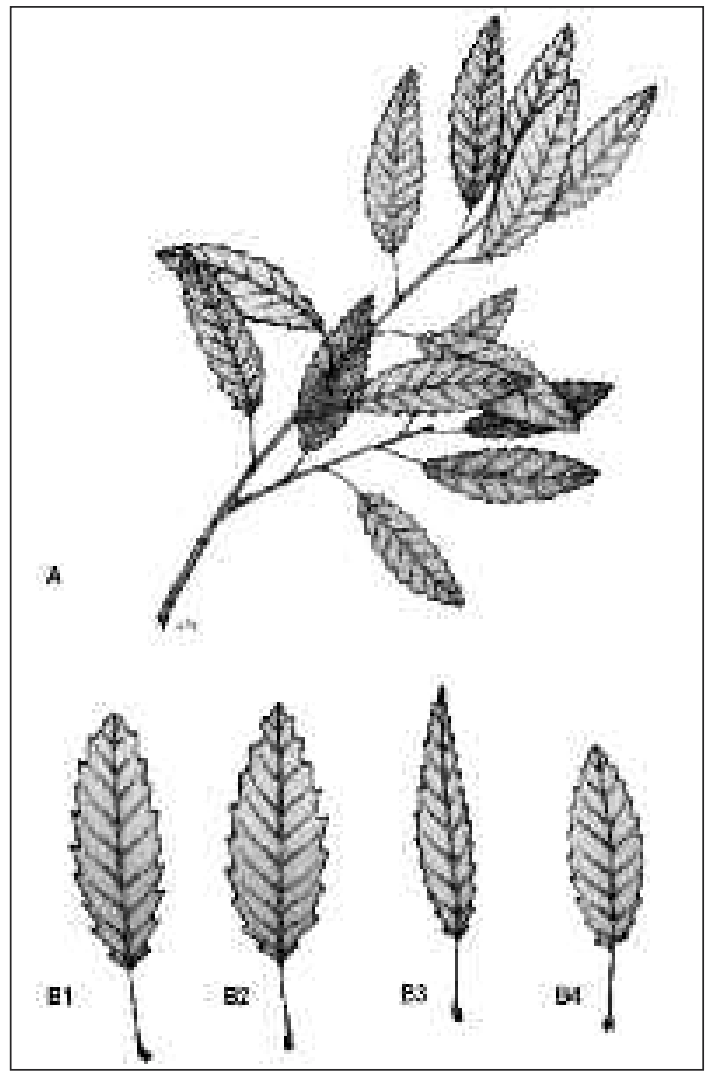

Figure 1. - Quercus gaditana F.M.Vázquez, C. PintoGomes \& C. Vila-Viçosa. A: Branche fraction; B1, B2, B3, B4: Leaves types morphologies

The presence of hybrids between $Q$. gaditana and Q. canariensis is frequent in southern Iberia, and this hybrid was described as: Quercus x salzmanniana (Webb) Cout. Bol. Soc. Brot. Ser. II 10: 76 (1935); basionym: $=$ Q. lusitanica Lam. $\gamma$ salzmanniana Webb. It. Hisp.: 12 (1838); lectotype: FI-WEB, n.v. isotype: P06857826! (left above specimen $) ;=Q$. canariensi Willd. $\mathrm{x} Q$.gaditana F.M. Vázquez, C. Pinto-Gomes \& C. Vila-Viçosa; $=Q$. canariensis Willd. var. salzmanniana (Webb) C. Vicioso, Bol. Inst. For. Invest. \& Exper. Madrid 51:94 (1950); = Q. xclementei C. Vicioso, Bol. Inst. For. Invest. \& Exper. Madrid 51:140 (1950) (holotype: MAIA6532!; paratype: MAIA6530 $!=Q$. xvillariana nothosubsp. clementei (C.Vicioso) F.M.Vázquez, S.Ramos \& S.García Int. Oaks 15: 31. (2004). Study of foliar trichomes and limb morphology of Q.alpestris Boiss. indicate the possible hybrid origins. This 
hypothesis is supported by the sporadic distribution of this taxon in Southern Iberian Peninsula. Then we propose the following: Quercus x alpestris Boiss. Elech.Pl.Nov.: 83 (1838) prop. sp. $(=$ $Q$. faginea Lam. x $Q$. suber L.).

As mentioned in Coutinho (1888), but omitted in Franco (1971), Q. gaditana was recently reinstated by Pinto-Gomes \& Paiva-Ferreira (2005), as $Q$. faginea subsp. alpestris for specific limestone's area in Barrocal Algarvio, concretely in Quercetum alpestris-broteroi forest association. In our taxonomic framework this taxon has been recognized several times in the same region, with indifferent behaviour for edaphic conditions, occurring also on schistose soils from Serra do Caldeirão till Seixe river basin, mainly among $Q$. marianica and Avenella stricta community (VILAViçOSA, 2012).

Ecology: As a south-western Iberian endemism, this taxon exists from thermo to supramediterranean, subhumid to hyperhumid bioclimatic belts, and copes with temporary waterlogging.

Quercus estremadurensis O.Schwarz, Notizbl. Bot. Gart. Berlin-Dahlem 12: 463. (1935) (lectotype: In JE n.v.; isotype: P06857428!)

Synonym: $=Q$. robur subsp. estremadurensis (O. Schwarz) A.Camus, Chênes, Atlas 2: 50 (1935); = Q. robur var. conimbricensis A.Camus, Bull. Soc. Bot. France, 81: 815 (1934) (lectotype: P06857428! $)=$ Q. racemosa Brot., Fl. Lusit. 2: 31 (1804) (P06856882!) non Lamarck, Encycl. [J. Lamarck \& al.] 1(2): 715 (1785).

Description: Marcescent tree to $20 \mathrm{~m}$ tall, with anfractuous branches. Irregular (rhomboidal) sclerophilous leaves, lobate (acute lobes), with intercalary veins and very short petiole (almost null). Adaxial surface glabrous and abaxial surface glabrous to glabrescent, sometimes with stellate trichomes, or simple, dispersed mainly in the primary vein (midrib) and less times in secondary veins.

Some controversy about its validation as an autonomous taxon is presented by HUGUET DEL VILLAR (1958), who states that it does not present an sinecologic and geographic identity, that would allow its endorsement as a distinct subspecies. The author claims that the subtle leaf mor- phology difference, observed by Schwarz, is due to phenotypic plasticity inside $Q$. robur $\mathrm{L}$. or to observation of vernal leaves. However, due to the characteristics related above and the complete geographic segregation observed in Q. robur subsp. broteroana, which can be related to the phytoclimatical distinction between typical Temperate and Mediterranean areas, we conclude this is a valid autonomous taxon for the Portuguese flora, as well as being recognized and scientifically validated in Spain. Phytosociologically, its phenological features are related to Quercion broteroi alliance, being a taxon related to thermophilous and humid areas. This is probably an ancient species involved in the formation of Q. robur, as referred by O. Schwarz in Huguet del Villar (1958), together with $Q$. hartwisiana.

The individuals found show mainly high foliar areas, being the leaves from younger branches smaller, sometimes mucronate. Other individuals suggest introgression with $Q$. broteroi $(Q$. x beturica), Q. marianica and $Q$. pyrenaica $(Q$. x subandegavensis).

Distribution: It has a wide range, being found in the midst of Q. marianica and Avenella stricta community, around Serra do Caldeirão, throughout Oudeloca and Seixe River basins, as well as in Brejeira, Carqueja, São Luis, Cercal and Grândola mountain ranges (Monchiquense district). It also occurs in Arisaro simorrhini-Quercetum broteroi forest association in Arrábida (Arrabidense district) as well as in Arisaro simorrhini-Quercetum pyrenaica, occurring also in the Centre Region of Portugal in Beirense Meridional and Estremenho Português districts. It has a high conservational value, as its distribution is almost entirely of the center-western part of Iberian Peninsula, with the main area in Portuguese mainland.

Ecology: Apparently this taxon is also an indifferent species for edaphic conditions, occurring on limestone soils, but probably linked to decarbonation, as a result of leaching. Being preferentially silicicolous and supporting permanent waterlogging, it occupies mostly temporihygrophilous situations, placing itself between edaphohygrophilous and climatophilous vegetation series, almost entirely related to phreatic conditions. 
Quercus marianica C.Vicioso, Bol. Inst. For. Inv. Exp. Madrid 51: 192. (1950) prop hybr.

Holotype: MAIA 6593! (central specimen), paratype 1: MAIA 6708! (single specimen); paratype 2: MAIA 6712! (upper specimen).

Synonyms: $=Q$. lusitanica auct. pl. non Lamarck, Encycl. [J. Lamarck \& al.] 1(2): 719 (1785) (Lectotype: P-LAM 00382467! (single specimen); $=Q$. canariensis auct. $p l$. non Willdenow, Enum. Pl. 2: 975 (1809) (lectotype: B-W 17608-01! (single specimen).

Description: Marcescent tree to $15 \mathrm{~m}$ tall. Abaxial leaf surface glabrescent and adaxial surface glabrous. Leaf narrowed in proximal edge, and progressively obovate towards the apex. Greyish indumentum and presence of fuzzy tomentum, scarce and deciduous, mainly in the midrib. Presence of stellate trichomes, some tetraradial with long radia (30-100 $\mu \mathrm{m})$ and frizzy, others flattened and more or less persistent. High number of secondary veins (11-13), rectilinear and protruding. Petiole from 5 to $15 \mathrm{~mm}$.

Ecology: Acidophilous to neutro-acidophilous, eu-hyperoceanic, thermo to mesomediterranean, dry to humid bioclimatic belts.

Distribution: In the study area, this taxon occurs throughout Monchiquense district, from Caldeirão to Grândola hills, and in all mountain ranges of Algarve and Alentejo Litoral.

This taxon is relevant to the core issue of this article, as it consists a hybrid species resulting from parents $Q$. broteroi and $Q$. canariensis. As shown in Table 1, this taxon presents important morphological differences with the original description of as shown in Table 1, this taxon presents important morphological differences with the ori-

Table 1

Comparative characteristics between Quercus marianica and Quercus canariensis

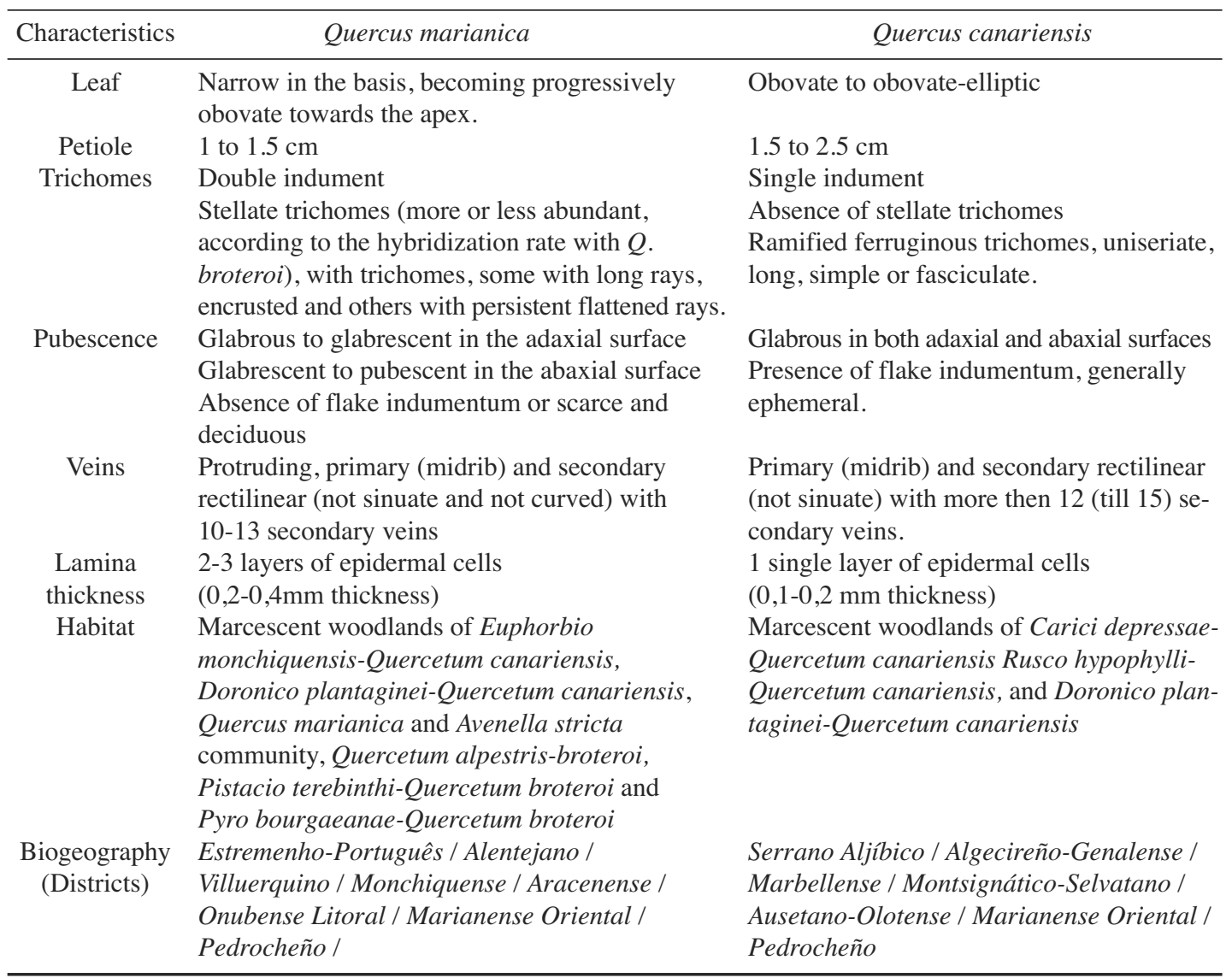


ginal description of Quercus canariensis (WILDENOW, 1809). Q. canariensis (WILDENOW, 1809). Speciation as a result of hybridism, due to occupation of new adaptive zones, for instance extreme habitats, relating to at least one of the parents, or high ecological disturbance promotes the formation of newly stabilized species from hybrids, as the concept of hybrid-species is introduced by NASOM \& al., (1992), RIESEBERG (1997), HuXel (1999) and VALbuena-CARABAÑA \& al. (2005) in Oliveira (2006).

Despite the issue about taxonomic affiliation for this taxon, the characteristics recognised in the foliar morphology (Table 1), allows us to relate it with $Q$. marianica C. Vicioso that was well documented in SAÉNZ \& RIVAS-MARTíNEZ (1971) and VASCONCELlOS \& FRANCO (1954). The glabrescent abaxial leaf surface and the progressively obovate leaf towards the apex, as well as the number of rectilinear and protruding nerves $(>11)$ are the main features allowing us to ally this taxon with the canariensis group of Quercus. The presence of stellate trichomes, with large rays, and the density of stellate trichomes, should allow us to infer about introgression rate with $Q$. broteroi (SAÉNZ \& RIVAS-MARTÍNEZ, 1971). This is corroborated by the thicker lamina, shorter petiole and leaf area (smaller), leading us to propose this stabilized species as $Q$. marianica $\mathrm{C}$. Vicioso, beside the absence of fasciculate and ferruginous trichomes, producing a deciduous flaky texture.

The dominant presence of $Q$. marianica belongs to the marcescent woodlands of Caldeirão, Monchique, Espinhaço de Cão, Brejeira, Carqueja, São Luis, Cercal and Grândola mountain ranges (Monchiquense district). Although, recent punctual references have been found, trough field surveys, in the midst of Arisaro simorrhini-Quercetum broteroi in Estremenho Português. This may suggest that the references of $Q$. mirbeckii Durieu for Montachique (Welwitsch) and Setubal (Allorge) (CAmus, 1938), may be pertinent as they may refer to $Q$. marianica, confirming its wider distribution inserted in Quercion broteroi woodlands, as in Spain (Extremadura) it may reach northern latitudes like the mountains of Las Villuercas, which suggests it can be promptly spread throughout the biogeographic subsector Oretano.

$Q$. canariensis Willd. was not found in the study area, and evidence in Portugal of $Q$. canariensis Willd. is probably difficult to attain, being very rare, as in the Marianense Oriental district, or even erroneously included in the Portuguese flora. The studied taxon (Q. marianica) is the prominent species on the Portuguese mainland, as several workers point out (CAPELO, 2007; ARSÉNIO \& al., 2009). Although VASCONCELlOS \& FRANCO (1954) refer to the rarity of $Q$. canariensis versus $Q$. marianica (the first one limited to the syenite batholith of Monchique mountains), also SAÉNZ DE RIVAS (1968) while justifying the presence of Q. marianica C. Vicioso in Spain, claims that the parent population is originally from Monchique, due to the greater distance from Aracena and Sierra Morena mountains, where $Q$. marianica is a recurrent taxon.

All analysed individuals collected through exhaustive fieldwork, then morphologic study and combination of biometric data correspond to $Q$. marianica $\mathrm{C}$. Vicioso. These observations, allied to the hybrid species definition, as well as $\mathrm{HU}$ GUET DEL VILLAR (1958) assertion of hybridogenous forests in northern Morocco and southern Spain, containing possible synonym $Q$. x fagineomirbeckii Villar, and his paradigmatic example of $Q$. subpyrenaica Villar, as other recently elevated hybrid species, allowed us to propose $Q$. marianica C. Vicioso as species (Table 1).

ORIGINAL OAK HYBRIDS FOUND IN THE STUDY AREA

Quercus xlousae C.Vila-Viçosa, F.M.Vázquez, Meireles \& C.Pinto-Gomes nothosp. nov.

$=Q$. estremadurensis $\mathrm{O}$. Schwarz x Q. marianica $\mathrm{C}$. Vicioso

Stirpem hybridam inter Q. estremadurensis et Q. marianica. Foliis breviter petiolatis $(<0,8$ $\mathrm{cm})$, basi subcordatis, lamina breviter lobulatis, mисronatis, supra glaberimis, subtus glaberimis vel pubescentis, cum pilis stipitatis et bulbosis.

Holotype: LUSITANIA: Sabóia, São Teotónio, Odemira, 20-V-2011, C. Vila-Viçosa et F.M. Vázquez HSS 54487 (right specimen). Isotype: HSS 54488, MAF, MA 
Dedicata: Professor Doutor Lousã, Mário Fernandes (1940), Insignis magister et botanicus

Description: Marcescent tree to $20 \mathrm{~m}$ high. Flat leaves, sclerophilous, lobate (acute lobes), with very short and red petiole $(<1 \mathrm{~cm})$. Adaxial surface glabrous and abaxial surface glabrous to glabrescent, sometimes with stellate and tetraradial and frizzy trichomes (30-100 $\mu \mathrm{m})$, others applied and more or less persistent. Higher number of secondary veins (till 11), rectilinear and protruding. (Figure 2, Table 2).

Ecology: Siliceous and thermomediterranean, with low continentality indexes (at least Evident Eu-oceanic)

Distribution: Like its parents, this taxon is exclusive to the Monchiquense district, following South-Western Littoral Mountains, from Caldeirão to Grândola Hills. The main differences between this hybrid and its parents are explained in Table 2.

Quercus xrosa-pintii C.Vila-Viçosa, F.M.Vázquez, Meireles \& C. Pinto-Gomes nothosp. nov.

$=Q$. broteroi (Cout.) Rivas-Mart. \& C. Sáenz x $Q$. marianica $\mathrm{C}$. Vicioso

Stirpem hybridam inter $Q$. broteroi et $Q$. marianica. Foliis breviter petiolatis $(<1,2 \mathrm{~cm})$, basi cordatis, lamina breviter lobulatis, mucronatis, supra glaberimis, subtus pubescentis vel tomentosis, cum pilis solitaris, stellatis et multiradiatis.

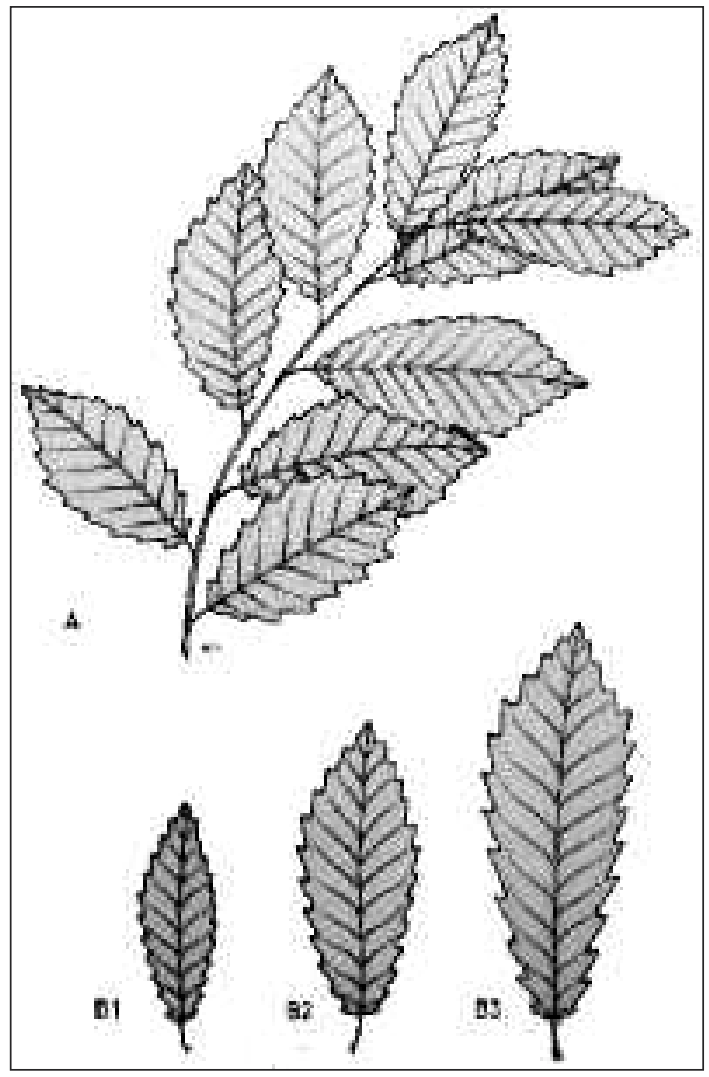

Figure 2. - Quercus xlousae C.Vila-Viçosa, F.M.Vázquez, Meireles \& C.Pinto-Gomes. A: Branche fraction; B1, B2, B3: Leaves types morphologies.

Table 2

Comparisons between Quercus xlousae and its parents

\begin{tabular}{|c|c|c|c|}
\hline Characteristics & Q. marianica & Q.xlousae & Q. estremadurensis \\
\hline Leaf morphology & $\begin{array}{l}\text { Progressively obovate } \\
\text { towards the apex, convex }\end{array}$ & $\begin{array}{l}\text { Progressively obovate } \\
\text { towards the apex, flat }\end{array}$ & Rhomboidal, flat \\
\hline Leaf margin & Lobulate & Lobulate & Lobulate \\
\hline Marginal spines & Absent & Absent or present & Absent or present \\
\hline Nerves & Protruding, rectilinear $>10$ & Protruding, rectilinear $<9$ & Not protruding, mostly sinuate $<8$ \\
\hline Pubescence & $\begin{array}{l}\text { Abaxial surface glabrescent, } \\
\text { Adaxial surface glabrous }\end{array}$ & $\begin{array}{l}\text { Abaxial surface glabrous } \\
\text { to glabrescent, Adaxial } \\
\text { surface glabrous }\end{array}$ & Both surfaces glabrous \\
\hline Petiole length mm & $(8-) 10-15(-18)$ & $\begin{array}{l}(4-) 6-5(-8) \text { reddish } \\
\text { of trichomes above }\end{array}$ & $3(-5) \mathrm{red}$ \\
\hline Simple-uniseriate & Absent & Scarce & Scarce \\
\hline Bulbous & Absent & Present & Present \\
\hline Solitary & Present & Scarce & Scarce \\
\hline Fasciculate & Absent & Absent & Absent \\
\hline Multiradiate & Present & Scarce & Absent or Present \\
\hline Stellate & Present & Scarce & Absent or Present \\
\hline Fused-stellate & Absent & Absent & Absent \\
\hline
\end{tabular}


Holotype: LUSITANIA: Cemitério de São Teotónio, São Teotónio, Odemira, 20-V-2011, C. Vila-Viçosa et F. M. Vázquez HSS 50596 Isotype: MAF, MA

Dedicata: Coronel Rosa Pinto, José Manuel Baptista (1941) Insignis algarbiorum botanicus

Description: Marcescent tree to $15 \mathrm{~m}$ tall. Abaxial leaf surface pubescent and adaxial surface glabrescent. Leaf oblong, lightly obovate towards the apex. Greyish indumentum with high presence of stellate trichomes, some frizzy. Protruding veins, with higher number of secondary veins (10-11), mostly rectilinear, and sometimes sinuate. (Figure 3, Table 3).

Ecology: Edaphic indifferent, thermo to mesomediterranean, dry to sub-humid in euhyper-oceanic areas of Monchiquense district. It occurs more often amongst mixed calcicolous materials above siliceous bedrock where $Q$. broteroi assumes a higher relative frequency facing $Q$. marianica.

Distribution: Following its parents, it presents a high range of distribution, being present in almost all refugia of $Q$. marianica woodlands in Monchiquense mistrict, following South-Western Littoral Mountains, from Caldeirão to Grândola Hills. The main differences between this hybrid and its parents are explained in Table 3.

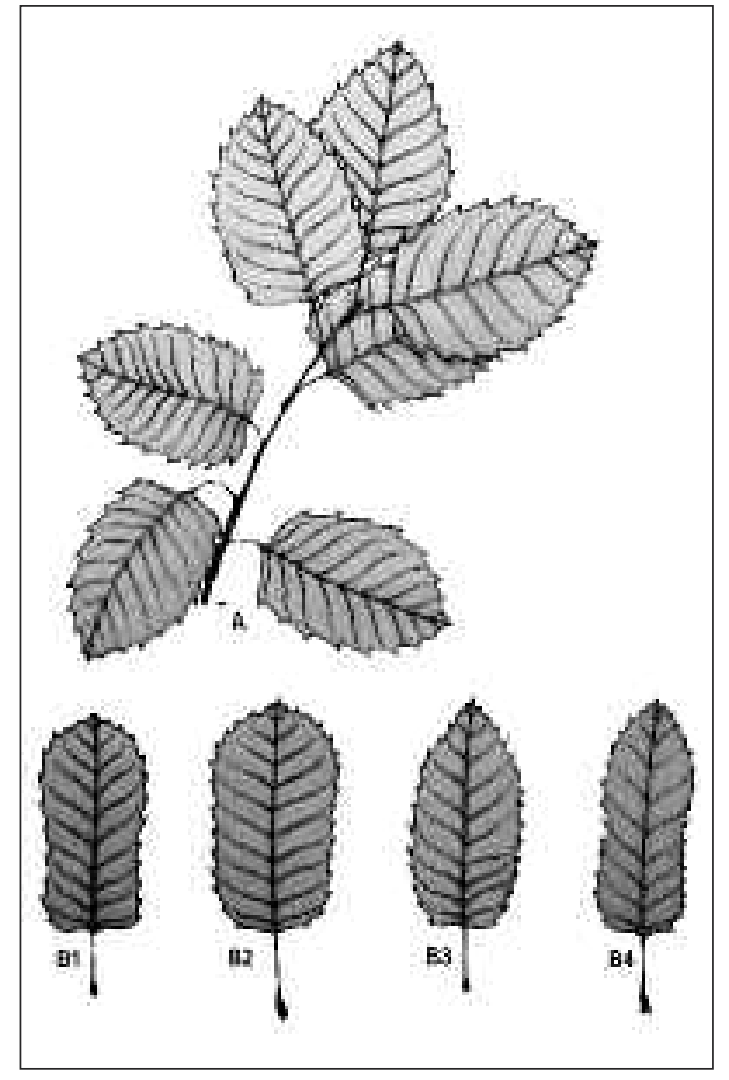

Figure 3.-Quercus xrosa-pintii C.Vila-Viçosa, F.M.Vázquez, Meireles \& C.Pinto-Gomes. A: Branche fraction; B1, B2, B3, B4: Leaves types morphologies.

Table 3

Comparisons between Quercus xrosa-pintii Vila-Viçosa, F.M. Vázquez, Meireles \& Pinto-Gomes and its parents

\begin{tabular}{llll}
\hline Characteristics & Q. marianica & Q.xrosa-pintii & Q. broteroi \\
\hline Leaf morphology & $\begin{array}{l}\text { Progressively obovate } \\
\text { towards the apex }\end{array}$ & $\begin{array}{l}\text { Progressively obovate } \\
\text { towards the apex }\end{array}$ & Oblong to Ovate/obovate \\
Leaf margin & Lobulate & Lobulate & Lobulate \\
Marginal spines & Absent & Absent or present & Absent or present \\
Nerves & Protruding, midrib and & Protruding, midrib and & Not protruding, mostly sinuate, \\
& secondary rectilinear $>11$ & secondary rectilinear $>10$ & with midrib sinuate in apex $<9$ \\
Pubescence & Abaxial surface glabrescent, & Abaxial surface pubescent, & Abaxial surface tomentose, \\
& Adaxial surface glabrous & Adaxial surface glabrescent & Adaxial surface pubescent \\
Petiole length mm & (8-)10-15(-18) & (4-)5-10(-12) & 5 -12(14) \\
& & Types of trichomes above & \\
Simple-uniseriate & Absent & Present & Present \\
Bulbous & Present & Present & Absent \\
Solitary & Absent & Present & Present \\
Fasciculate & Absent & Absent & Present \\
Multiradiate & Present & Present & Present \\
Stellate & Present punctual & Present & Present Abundant \\
Fused-stellate & Absent & Absent & Absent \\
\hline
\end{tabular}


Other described taxa are mentioned below, with their updated definitive distribution within the study area:

Quercus xandegavensis nothosubsp. henriquesii (Franco \& Vasc.) Rivas-Mart. \& Sáenz, Rivasgodaya 6: 108 (1991)

Synonym: $Q$. xhenriquesii Franco \& Vasc., An . Inst. Sup. Agron., Lisboa 21: 25. (1954)

$=Q$. pyrenaica Willd x $Q$.robur subsp. broteroana $\mathrm{O}$. Schwarz

Individuals found with related characteristics present low morphological variation, being easily determined as Q.xandegavensis nothosubsp. henriquesii, when considering leaf morphology (pinatilobate, with round lobes and abaxial leaf surface glaucous and with a dense indumentum, dominated or punctuated by fasciculate trichomes).

Distribution: This taxon occurs frequently in $\mathrm{Vi}$ burno tini-Quercetum broteroana woodlands, beside edaphoxerophilous situations, groves of Arisaro simorrhini-Quercetum pyrenaica, or even in forests with major oceanic influence, for example in Salão Frio (São Mamede mountains) and Ponte de Sôr.

Quercus xsubandegavensis A.Camus, Chênes Atlas 2: 601935.

$=Q$. estremadurensis $\mathrm{O}$.Schwarz x $Q$. pyrenaica Willd.

We have found individuals showing high irregularity with regard to leaf morphology and present different hybridization rates between parents, with acute lobes and more or less pinnate leaf margin, being the glabrescence of adaxial leaf surface, related to the tomentose abaxial leaf surface and shorter and reddish petiole, the main characters that diagnose this taxon.

Distribution: This taxon was found in the southwestern part of the study area, namely in Lameiros (Serra de S. Luis), Portela (São Teotónio) and Gavião (Serra do Caldeirão). In this area the taxon is limited by the occurrence of $Q$. pyrenaica Willd., but has a wider distribution in the study area, being present the central and south regions of Portugal.

Quercus xbeturica (F.M.Vázquez, A. Coombes, M. Rodriguez-Coombes, S. Ramos \& E. Doncel) F.M.Vázquez, C.Vila-Viçosa, Meireles
\& C. Pinto-Gomes stat. nov.

Synonym: $Q$. xcoutinhoi nothosubsp. beturica F.M.Vázquez, A. Coombes, M. Rodriguez-Coombes, S. Ramos \& E. Doncel, Int. Oaks 14: 53(2003)

$=$ Q. broteroi (Cout.) Rivas-Mart.. \& C. Sáenz x Q.estremadurensis O. Schwarz

Distribution: The individuals representing this taxon were found throughout the Rio Mira river basin sites, and later at Serra de Montejunto, already known from Estremenho Português district, with a probably wider range of distribution in the entire study area. It is found in Q. marianica C. Vicioso and Avenella stricta communities but is also present in Arisaro simorrhini-Quercetum broteroi woodlands. Although this taxon does not present any morphological variation, all individuals are easily classified by the steady presence of stellate trichomes in the abaxial leaf surface.

Quercus xneomairei A.Camus, Riviera Sci. 24: 38. (1937)

$=$ Q. broteroi (Cout.) Rivas-Mart. \& C. Sáenz x $Q$. pyrenaica Willd.

Despite only being collected in Serra de Monfurado (Alentejano district), with penatilobate leafs and the abaxial surface laden with stellate and fasciculate trichomes, and both surfaces tomentose to velvety, its distribution range should be much wider, being cited by CosTA \& al. (1998) as being in several other biogeographic districts, in Arisaro simorrhini-Quercetum pyrenaicae woodlands.

Being referenced by FRANCO (1990), the illegitimate name record as $Q$. xwelwitschii Samp., deserves critical study, as it is previously described by SAMPAIO (1910), before Camus (1938). The nomenclatural issue about this taxon may be clarified as resulting from introgression between the two parents (Q. broteroi (Cout.) Rivas-Mart. \& C. Sáenz and Q. pyrenaica Willd.).

\section{CONCLUSIONS}

As shown, the marcescent oak woodlands in Southern Portugal are intimately connected with mountainous areas, or specific edaphic typologies which understanding has led to several advances, 
including taxonomic aspects of this theme. The biogeographic approach reveals a high intertaxonomic relationship between the leading species associated to climatophilous vegetation and the rest of marcescent oaks.

This study provides increased knowledge of Quercus taxonomy, namely in two previously unrecognized taxa $(Q$. gaditana and $Q$. estremaduresis) as well as providing information about the supposed occurrence of $Q$. canariensis Willd. in Portugal, which should correspond now to the newly elevated species $Q$. marianica C. Vicioso and related to the hybrid-species originally described as $Q$. x marianica $\mathrm{C}$. Vicioso by Vicioso (1950). The conservational status of Q. canariensis Willd. as Vulnerable, should be revised because Andalusian populations remain only as relict traces, of approximately 2.5 ha of this species, following BLANCA \& al. (2000).

Additionally, there are four nothotaxa (Q.xan- degavensis nothosubsp. henriquesii, Q.xsubandegavensis, $Q$. xbeturica and $Q$.xneomairei) referring to hybridisation in marcescent oaks. We have described 2 new nothosubspecies related to Q. marianica (Q.xlousae and Q.xrosa-pintii).

This results along with taxonomic updates, gives confidence in studies addressing detailed vascular plant taxonomy, contrary to the prevailing idea that taxonomic work on vascular plants is defunct (AgNARSSON \& KunTNER 2007), and unappealing compared with other branches of modern biologic sciences (GODFRAY, 2005).

\section{ACKNOWLEDGEMENTS}

The authors would like to thanks POCTEP OTALEX C project for providing excursions that greatly improved the knowledge documented in the main subject of this article. This article also benefited from native-language review by Maria Cullen and Howard Fox.

\section{REFERENCES}

Abadía, A., Gil, E., Morales, F., Montañés, L., Montserrat, G. \& Abadía, J. - 1996- Marcescence and Senescence in a submediterranean Oak (Quercus subpyrenaica E.H. Villar): Photosynthetic characteristics and nutrient composition - Plant Cell and Environment. 19: 685-694.

Agnarsson, I. \& Matjaz-Kuntner, M. -2007- Taxonomy in a Changing World: Seeking Solutions for a Science in Crisis - Syst. Biol. 56(3):531-539.

Aguiar, C., Monteiro-Henriques, T. \& Sánchez-Mata, D. 2013 - New contributions on Flora and Vegetation of notheastern Portugal ultramafic outcrops - Lazaroa 34: 141-150.

Alonso, R., Llamas, F., Puente, E. \& Penas, A. -1999- A new nothospecies of the genus Quercus L. (Fagaceae) - Bot. Helvetica. 109. 91-96.

Arsénio, P., Neto, C., Monteiro-Henriques, T. \& Costa, J.C. -2009- Guia geobotânico da excursão ALFA 2009 ao litoral alentejano - Quercetea 9: 4-42.

Axelrod, D.I. - 1983 - Biogeography of Oaks in the ArctoTertiary province - Ann. Miss. Bot. Gard. 70: 629-657.

Bacilieri, R., Ducousso, A., Petit, R.J. \& Kremer, A. -1996Mating system and asymmetric hybridization in a mixed stand of European Oaks - Evolution 50: 900-908.

Benson, L. - 1962 - Plant Taxonomy, Methods and Principles - Ronald Press, New York.

Blanca, G., Cabezudo, B., Hernández-Bermejo, J.E., Herrera, C.M., Muñoz, J. \& Valdés, B. -2000 - Quercus canariensis - In: Libro Rojo de la Flora silvestre amenazada de Andalucía. Tomo II. Especies vulnerables, Pp. 299-302. Cons. Medio Amb., Junta de Andalucía, Sevilla.
Burger, W.C. - 1975 - The species concept in Quercus Taxon 24(1): 45-50.

Camus, A. - 1938 - Les chénes. Monographie du genre Quercus, 1 - Lechevalier. Paris.

Capelo, J. -2007- Nemorum Transtaganae Descriptio: Sintaxonomia Numérica das Comunidades Florestais e Pré-florestais do Baixo Alentejo - Mem. Doc. (ined.). Inst. Sup. Agron. Univ. Téc. Lisboa.

Castroviejo, S. \& al. (Eds.) - 1986-2012 - Flora Iberica 1-8, 10-15, 17-18, 21 - Real Jardín Botánico, CSIC, Madrid.

Costa, J.C., Aguiar, C., Capelo, J., Lousa, M.F. \& Neto, C. -1998- Biogeografia de Portugal Continental Quercetea 0: 5-56.

Cottam, W.P.,Tucker, J.M., Drobnick, R. - 1959- Some clues to Great Basin postpluvial climates provided by Oak distributions - Ecology 40: 361-377.

Coutinho, A.X.P. - 1888- Os Quercus de Portugal - Bol. Soc. Brot. sér. 1, 6: 47-116.

Dodd, R.S. \& Afzal-Rafii, Z. -2004- Selection and dispersal in a multispecies Oak hybrid zone - Evolution 58(2): 261-269.

Franco, J.A. \& Rocha-Afonso, M.L. - 1994-2003- Nova Flora de Portugal (Continente e Açores). Vol. 3, fasc. IIII - Ed. Escolar, Lisboa.

Franco, J.A. - 1971, 1984 - Nova Flora de Portugal (Continente e Açores). 3 vols. - Edição do autor, Lisboa.

Franco, J.A. - 1990 - Quercus L. - In: Castroviejo, S. \& al. (Eds.). Flora Iberica, vol. 2, pp.15-36. Real Jardín Botánico, CSIC, Madrid. 
Gavilán, R.G., Vilches de la Serna, B. \& Fernández-González, F. - 2011- Syntaxonomical review of Cytisetea scopariostriati communities in central Spain - Lazaroa 32: 29-72.

Godfray, H. - 2005- Taxonomy as Information Science. Proc. Calif. Acad. Sci. 56: 170-181.

Hardin, J.W. - 1979 - Atlas of foliar surface feactures in woody plants I. Vestiture and trichomes types of Eastern North American Quercus. Bull. Torrey Bot. Club 106(4): 313-325.

Himrane, H., Camarero, J.J., Gil-Pelegrín, E. -2004Morphological and ecophysiological variation of the hybrid Oak Quercus subpyrenaica (Q. faginea $\times$ Q. pubescens) - Trees;18:566-575

Holmgren, P.K. \& Holmgren, N.H. - 2003 - Additions to Index Herbariorum (Herbaria), edition 8- Fourteenth Series. Taxon 52: 385-389.

Holmgren, P.K.; Holmgren, N.H. \& Barnett, L.C. - 1990Index Herbariorum Part I: The herbaria of the World, ed. 8.- Regn. Vegetabile 120: 1-693.

Huguet del Villar, E.H. - 1958 - Estudio sobre los Quercus del Oeste mediterráneo. An. Inst. Bot. Cavanilles, 15: 3-114.

Llamas, F., Perez-Morales, C., Acedo, C., Penas, A. 1995 - Foliar trichomes of the evergreen and semi-deciduous species of the genus Quercus (Fagaceae) in the Iberian Peninsula. Bot. J. Linn. Soc. 117, 47-57.

Manos, P.S., Doyle, J.J., Nixon, K.C. -1999- Phylogeny, biogeography, and processes of molecular differentiation in Quercus subgenus Quercus (Fagaceae) - Mol. Phylogenet. Evol. 12:333-349

Manos, P.S., Zhou,Z.K., Cannon, C.H. -2001- Systematics of Fagaceae: phylogenetic tests of reproductive trait evolution. Int. J. Plant Sci. 162:1361-1379

Muller, C.H. - 1951. The Oaks of Texas. Contrib. Texas Res. Found. 1(3): 21-323.

Muller, C.H. - 1952 - Ecological control of hybridisation in Quercus: a factor in the mechanism of evolution. Evolution 6: 147-161.

Oliveira, P. -2006 - A análise isoenzimática na identificação de híbridos de sobreiro e azinheira. Prova de Doutoramento. Univ. Évora. 293 pp.

Palmer, E.J. - 1948 - Hybrid Oaks of North America - J. Arnold Arbor. 29: 1-49.

Penas, A., Llamas, F., Perez-Morales, C., Acedo, C. 1997- A new species of Quercus L. (Fagaceae) from NW Spain - Bot. Helvetica 107: 75-82.

Pinto-Gomes, C. \& Paiva-Ferreira, R. -2005 - Flora e Vegetação do Barrocal Algarvio (Tavira- Portimão) CCDR, Algarve. $350 \mathrm{p}$.

Rieseberg, L.H., Archer, M.A. \& Wayne, R.K. - 1999Transgressive segregation, adaptation, and speciation Heredity 83:363-372

Rivas-Martínez, S. -2007- Mapas de series, geoseries y geopermaseries de vegetación de España, parte I - Itinera Geobot. 17: 5-436.

Rivas-Martínez, S. - 2011 - Mapas de series, geoseries y geopermaseries de vegetación de España [Memoria del mapa de vegetación potencial de España], parte II - Itinera Geobot. 18: 5-800.

Rivas-Martínez, S. \& Saénz, C. - 1991 - Enumeración de los Quercus de la Península Ibérica - Rivasgodaya 6: 101-110.

Rushton, B.S. - 1993 - Natural hybridization within the genus Quercus - Ann. Sci. For. 50: 73-91.

Saénz de Rivas, C. \& Rivas-Martínez, S. -1971 - Híbridos meridionales ibéricos del Quercus faginea Lam. Pharm. Med. 7: 489-501.

Saénz de Rivas, C. - 1968 - Notas sobre Quercus canariensis Willd. - An. Inst. Bot. Cavanilles 26: 45-52.

Sampaio, G. - 1910 - Plantas novas para a flora portuguesa. Ann. Sci. Acad. Polytec. Porto 3: 157-160.

Sánchez de Dios, R., Benito-Garzón, M. \& Sainz-Ollero, H. -2006- Hybrid zones between two European Oaks: a plant community approach - Plant Ecol. 187: 109-125.

Sciandrello, S., D’Agostino, S. \& Minissale, P. -2013Vegetation analysis of the Taormina Region in Sicily: a plant landscape characterized by geomorphology variability and both ancient and recent anthropogenic influences - Lazaroa 34: 151-190.

Stebbins, G.L. - 1950 - Variation and Evolution in Plants - Columbia Univ. Press, New York.

Vasconcellos, J.C. \& Franco, J.A. - 1954- Carvalhos de Portugal - An. Inst. Sup. Agron. 21: 1-135

Vázquez, F.M., Ramos, S. \& Ruiz, T. -2000- Hybridisation processes in Mediterranean Oaks from South Spain - Jour. Intern. Oak Soc. 12: 108-117

Vázquez, F.M. - 1995 - Híbridos de Quercus faginea subsp. broteroi (Coutinho) A.Camus en el suroeste de la Península Ibérica - Anal. Jard. Bot. Madrid 53(2): 247-251

Vázquez, F.M., Ramos S., Doncel E., Coombes, A.J. \& Rodríguez, M. - 2003 - New Oak hybrids from Spain Int. Oak J.14: 49-60.

Vicioso, C. - 1950 - Revisión del género Quercus en España - Trab. Inst. Invest. Exper. Forestales. Exp. 51. Madrid. 194 pp.

Vila-Viçosa, C. -2012- Os carvalhais marcescentes do Centro e Sul de Portugal - Estudo e Conservação. Diss. Mestrado. Univ. Évora Inst. Sup. Agron., Univ. Téc. Lisboa, Évora. 105 p.

Vila-Viçosa, C., Mendes, P., del Río, S., Meireles, C., QuintoCanas, R., Arsénio, P., Pinto-Gomes, C. - 2012- Temporihygrophilous Quercus broteroi forests in Southern Portugal: Analysis and conservation - Plant Biosyst. 146: 298-308.

Vilches de la Serna, B., Merle, H., Ferriol, M., SánchezMata, D. \& Gavilán, R.G. -2013 - Minuartio valentinae-Quercetum pyrenaicae: a new Iberian broad-leaved oak forest in the eastern coastal mountains and seral plant communities - Lazaroa 34: 209-217.

Willdenow, C.L. - 1809- Enumeratio Plantarum Horti Regii Botanici Berolinensis - Taberna Libraria Scholae Realis, Berolini. 1099 pp. 
APPENDIX 1

STUDIED MATERIAL:

Quercus alpestris Boiss. SPAIN: Badajoz: Trasierra, Sierra Morena, 25.03.1852, Lange (COIWILLK 38881). Ciudad Real: Fuencaliente, Umbría de las Tortillas, 10.10.1946, C. Vicioso (MAIA 6611, 6612). Málaga: Ronda, Sierra de las Nieves, 30SUF17, X-1837, P.E. Boissier (G00358088, Isotype1; G00358091, Isotype2; P06857844, Isotype3); ibídem, zonas cacuminales, 30SUF17, 27.09.1994. F.M. Vázquez (HSS 1220). PORTUGAL: Beira Litoral: Coimbra; Santa Clara, 10.1889, A. Moller (Flora Lusi. Exsic., no 874, P06857848, P06853571).

Quercus broteroi (Cout.) Rivas-Mart. \& C. Sáenz. SPAIN: Badajoz: Fuentes de León, 29SQC11, 19.08.1992, M. C. Pérez \& F. M. Vázquez (HSS 3720); Monesterio, Sierra de Tentudía, 29SQC31, 07.02.2001, Salvador \& F. M. Vázquez (HSS 7232); Salvaleón, bosque mixto de Quercus faginea, Q. rotundifolia y Q. suber, 29SPC96, 24.05.2001, J. Blanco, E. Doncel \& F. M. Vázquez (HSS 6604); Valle de Santa Ana, 29SPC94, 06.09.1995, F. M. Vázquez (HSS 16875). Cáceres: Villareal de San Carlos, Salto del Gitano, 29SQE51, 16.03.2006, S. Aguilar, J. Blanco, M. Gutiérrez \& F. M. Vázquez (HSS 18037). Cádiz: Arcos de la Frontera-El Bosque, cerca de Arcos de la Frontera, 30STF67, 14.08.2003, A. Coombes \& F.M. Vázquez (HSS 10384); El Bosque-Ubrique, 30STF76, 14.08.2003, A. Coombes \& F.M. Vázquez (HSS 10440). Huelva: Galaroza, 29SQC00, 11-X-2001, E. Doncel \& F. M. Vázquez (HSS 8523); Santa Ana la Real, bosques de Q. suber en vaguadas profundas muy sombrías, 29SQB09, 13-XI-2000, J. Blanco \& F. M. Vázquez (HSS 5219). PORTUGAL: Algarve: Loulé, Salir, serra calcária, 29SNB82, 26.04.2012, C. Pinto-Gomes, F.M. Vázquez \& C. Vila-viçosa (HSS 54332). Alto Alentejo: Aldeia Velha, zonas de margem de bosque e cultivos, 10.12.2011, L. Concepción, C. Pinto-Gomes \& F.M. Vázquez (HSS 54827); Estremoz, forest of Q. rotundifolia and Q. faginea, 29SPD20, 08.06.2001, F.M. Vázquez (HSS 6767); Montemor-o-Novo, Foros de Vale de Figueira, 29SNC58, 08.10.2010, J. Blanco, M. Cabeza de Vaca, D. García, C. Pinto-Gomes \& F.M. Vázquez (HSS 48681); Ponte de Sôr, Cano, 29SND84, 18.06.2000, S. Ramos \& F. M. Vázquez (HSS 5296). Baixo Alentejo: Grândola, 29SNC32, 13.01.2012, C. Vila-Viçosa (HSS 56730); Odemira, São Teotónio, proximidades do cemitério, 29SNB25, 20.05.2011, C. Pinto-Gomes, F.M. Vázquez \& C. Vila-Viçosa (HSS 50547). Estremadura: Setúbal, Serra da Arrábida, 29SNC06, 30.10.2010, J. Blanco, D. García, F.M. Vázquez \& al., (HSS 53553).

Quercus canariensis Willd. SPAIN: Cádiz: Alcalá de los Gazules a Puerto Galis, 30STF65, 14.08.2003, A. Coombes \& F. M. Vázquez (HSS 10387); Algeciras a Cádiz, 30STE79, 14.08.2003, A. Coombes \& F.M. Vázquez (HSS 10464); Los Barrios, paraje de La Montera del Torero, 30STF70, 20.11.2000, J. Blanco, S. Ramos \& F. M. Vázquez (HSS 26058); Ubrique a Cortés de la Frontera, 30STF85, 14.08.2003, A. Coombes \& F. M. Vázquez (HSS 10378). Málaga: Cortes de la Frontera, 30STF95, 29.07.1992, M. Pérez \& F. M. Vázquez (HSS 3465a). MOROCCO: Alhucemas: a 50 km de Ketama, bosque mixto de Q. pyrenaica y Q. canariensis, 14.05.2010, R. Ferreira, R. Gavilán, C. Pinto, D. Sánchez, F.M. Vázquez \& B. Vilches (HSS 49310). Mequinez: subida a Azrou, cedrales, 12.05.2010 R. Ferreira, R. Gavilán, C. Pinto, D. Sánchez, F.M. Vázquez \& B. Vilches (HSS 49658). Tanger: Bab el Berret, en bosques de Q. pyrenaica, Q. suber y Q. canariensis, 15.05.2010, R. Ferreira, R. Gavilán, C. Pinto, D. Sánchez, F.M. Vázquez \& B. Vilches (HSS 49187).

Quercus estremadurensis O.Schwarz. SPAIN: Badajoz: Valle de Santa Ana, 29SPC94, 2008, F.M. Vázquez (HSS 51443). PORTUGAL: Baixo Alentejo: Évora, Freguises, 29SNC76, 2011, C. VilaViçosa (HSS 54465); Grândola, 29SNC32, 13.01.2012, C. Vila-Viçosa (HSS 56734); Santiago do Cacém, Cercal, Serra do Cercal. 29SNB28, 27.06.2011, J. Blanco, C. Vila-Viçosa, C. Meireles, C. Pinto-Gomes \& F.M. Vázquez (HSS 51598); Odemira, Lameiras.,São Luis, 29SMC79, 2012, C. VilaViçosa (HSS 56717). 
Quercus gaditana F.M.Vázquez, C. Pinto-Gomes \& C. Vila-Viçosa. SPAIN: Badajoz: Hoya de Santa María, 29SQC51, 11.05.2001, E. Balbuena, E. Doncel, J. Pozo, S. Ramos \& F. M. Vázquez (HSS 5499). Cádiz: Algar, 30STF66, 14.08.2003, A. Coombes \& F. M. Vázquez (HSS 10520); Castellar de la Frontera, 21.06.2000, F.M. Vázquez (HSS 4854); Puerto de Galis, 28.10.2001, F.M. Vázquez \& al. (HSS 7509); Ronda in montibus circa, 30SUF17, 05.1837, 3600', P.E. Boissier (P06857823; P06857842); Yunquera, 1849, P.E. Boissier \& G.F. Reuter (P052098279); Ubrique a Cortes de la Frontera, 30STF85, 14.08.2003, A. Coombes \& F.M. Vázquez (HSS 10380). PORTUGAL: Algarve: Serra do Caldeirão, Bajo 29.05.2001, E. Doncel, S. Mendes, C. Pinto, Rodrigo \& F. M. Vázquez (HSS 6467); Aljezur, Odeceixe, 29SNB32, 20.05.2011, C. Pinto-Gomes, F.M. Vázquez \& C. Vila-Viçosa (HSS 50600). UNITED KINGDOM: Gibraltar (P-LAM 00382503, holotype; PLAM 00382502, isotype2; P-LAM 00382504, isotype1).

Quercus marianica C.Vicioso. SPAIN: Badajoz: Fuentes de León, cerro opuesto a Cueva del Cuervo, 29SQC21, 18.03.2008, M. Gutiérrez, F. Márquez, S. Ramos, S. Rincón \& F.M. Vázquez (HSS 36980); Salvatierra - Salvaleón, 29SPC96, 19.11.2002, F.M. Vázquez (HSS 11543); Valle de Santa Ana, 29SPC94, en bosques de alcornoques, 30.06.2002, F. M. Vázquez (HSS 11523). Cáceres: Alía, La Calera. Parte baja del Collado de Sobacorbas, 30SUJ07, 21 .06.2011, D. García \& F. Márquez (HSS 51233). Cádiz: Algar, 30STF66, 14.08.2003, A. Coombes \& F. M. Vázquez (HSS 10509); Ubrique a Cortés de la Frontera, 30STF85, 14-VIII-2003, A. Coombes \& F. M. Vázquez (HSS 10373). Huelva: Santa Ana la Real, Bosques de Q. suber en vaguadas profundas muy sombrías, 29SQB09, 13-XI-2000, J. Blanco \& F. M. Vázquez (HSS 5234). Jaén: Santa Elena, parque Natural de Despeñaperros, 30SVH54, 30.05.2011, M. Hervé, A. LeHardy, M. Timancheff \& F.M. Vázquez (HSS 50961). Málaga: Gaucín, 30STH97, 14.08.2003, A. Coombes \& F. M. Vázquez (HSS 10331). PORTUGAL: Algarve: Monchique, Ctr. EN267, Km. 32,4, 29SNB43, 20.05.2011, C. Pinto-Gomes, F.M. Vázquez \& C. Vila-Viçosa (HSS 50531). Baixo Alentejo: Grândola, 29SNC32, 13.01.2012, C. VilaViçosa (HSS 56732); Odemira, Vila Nova de Milfontes, 29SNB17, 2011, C. Vila-Viçosa (HSS 54490).

Quercus pyrenaica Willd. SPAIN: Badajoz: Cabeza la Vaca, sierra de Tentudía, 29SQC21, 21.10.1994, M. A. Suárez, M. P. Baselga \& F. M. Vázquez (HSS 1144); Monasterio, Alto de Sierrafría, hacía el Castillo, 29SQC41, 30.04.2007, D. García \& F.M. Vázquez (HSS 32404). Cáceres: Navatrasierra, ctra. CC20, km. 33,35, turbera de Hospital del Obispo, Garganta del Hospital, 30STJ98, 26.06.2012, J. Blanco, D. García, F. Márquez \& F.M. Vázquez (HSS 55451); Talayuela, Pinar del Moreno, 30TTK73, 11.05.2011, M. Cabeza de Vaca, D. García \& F. Márquez (HSS 50052); Tornavacas, Garganta de la Serrá., desde el Collado de Labradillas hasta La Sillita, 30TTK75, 27.06.2012, J. Blanco, D. García, F. Márquez \& F.M. Vázquez (HSS 55440). Huelva: Galaroza, castañar con retazos de melojar y alcornocal sobre sustrato calizo muy lavado, 29SQB09, 10-III-2012, J. Blanco, T. Ruíz \& J.M. Pavo (HSS 53377). PORTUGAL: Alto Alentejo: Ctra. Escoural - Montemor-o-Novo, 08.10.2010, J. Blanco, M. Cabeza de Vaca, D. García, C. Pinto \& F.M. Vázquez (HSS 48695); Estremoz, proximidades, 29SPD20, 07-II-2007, A. Gutierres, C. Pinto-Gomes, S. Ramos \& F. M. Vázquez (HSS 28733); Évora, Freguises, 29SNC76, 2011, C. Vila-Viçosa (HSS 56709). Beira Baixa: Fundão, Serra da Estrela, 29TPE24, 14.06.2012, F.M. Vázquez (HSS 55055). Baixo-Alentejo: Lameiras. São Luis, 29SMC79, 2012, C. Villa-Viçosa (HSS 56714).

Quercus robur L. subsp. broteroana O. Schwartz. SPAIN: Cáceres: Garganta la Olla, Ctra. Garganta la Olla-Cuacos de Yuste. Garganta de Pedro Chate, 30TTK64, 03.10.2006, J. Blanco \& F. M. Vázquez (HSS 28172). San Martín de Trevejo, 29TPE85, 25-IV-2001, J. Blanco, E. Doncel, A. Martín, S. Ramos \& F. M. Vázquez (HSS 5817). PORTUGAL: Beira Baixa: Manteigas, Penhas Douradas, entre Manteigas y Penhas Douradas, Robledal, 06.06.2000, M. Ladero \& S. Rivas-Martínez (HSS 54198).

Quercus $x$ andegavensis nothosubsp. henriquesii (Franco \& Vasc.) Rivas-Mart. \& Sáenz. PORTUGAL: Beira Baixa: Fundão, Serra da Estrela, 29TPE24, 14.06.2012, F.M. Vázquez (HSS 55056). 
Quercus $\boldsymbol{x}$ beturica (F.M.Vázquez, A. Coombes, M. Rodriguez-Coombes, S. Ramos \& E. Doncel) F.M.Vázquez, C.Vila-Viçosa, Meireles \& C.Pinto-Gomes. SPAIN: Badajoz: Valle de Santa Ana, 29SPC94, 1993, F.M. Vázquez (HSS 2451, holotype; 2452, isotype).

Quercus $\boldsymbol{x}$ lousae C.Vila-Viçosa, F.M.Vázquez, Meireles \& C.Pinto-Gomes. PORTUGAL: Baixo Alentejo: Sabóia, São Teotónio, Odemira, 20-V-2011, C. Vila-Viçosa \& F.M. Vázquez (HSS 54487, holotype).

Quercus $x$ neomairei A.Camus. SPAIN: Badajoz: Salvatierra de los Barros, Salvatierra de los Barros a Salvaleón. Finca "El Chorrero", 29SPC96, 04.12.2009, J. Blanco, M. Gutiérrez \& F.M. Vázquez, (HSS 43896). PORTUGAL: Baixo Alentejo: São Teotónio, Odemira, próximo a Espedanas, 29SNB25, 20.05.2011, C. Vila-Viçosa \& F.M. Vázquez (HSS43897).

Quercus $\boldsymbol{x}$ rosa-pintii C.Vila-Viçosa, F.M.Vázquez, Meireles \& C.Pinto-Gomes. PORTUGAL: Baixo-Alentejo: Cemitério de São Teotónio, São Teotónio, Odemira, 20-V-2011, C. Vila-Viçosa \& F.M. Vázquez (HSS 50596, holotype).

Quercus x salzmanniana (Webb) Cout. SPAIN: Huelva: Arroyomolinos de León, 26.10.1946, C. Vicioso (MAIA 6532). Ciudad Real: Fuencaliente, 10.10.1946, C. Vicioso (MAIA 6531); Puebla de Don Rodrigo, 8.10.1946, C. Vicioso (MAIA 6530). PORTUGAL: Baixo-Alentejo: Odemira, 29SNB36, 2011, C. Vila-Viçosa (HSS 54479). MOROCCO: Tanger: in vallibus ad occanus Tigitanus, montis Djijbel Kibir, D.B Webb (P06857826, isotype, left above specimen).

Quercus $x$ subandegavensis A.Camus. PORTUGAL: Baixo Alentejo: Sao Teotónio, Odemira, próximo a Espedanas, 29SNB25, 20.05.2011, C. Vila-Viçosa \& F.M. Vázquez (HSS 50583). 